\title{
Caracterização dos programas e dos principais parceiros privados do Pacto pela Educação do estado do Pará.
}

\author{
Marina A. de Souza (IC), Theresa M. de F. Adrião (PQ)
}

\section{Resumo}

Este trabalho, vinculado à pesquisa MAPEAMENTO DAS ESTRATÉGIAS DE PRIVATIZAÇÃO DA EDUCAÇÃO BÁSICA NO BRASIL (2005-2015), refere-se ao Programa Pacto pela Educação, em vigência no estado do Pará a partir de 2012, e busca caracterizar e identificar os principais parceiros e instituições da iniciativa privada que atuam diretamente na definição das diretrizes educacionais do estado. Por meio de levantamento em fontes disponíveis em sites oficiais das secretarias estaduais de educação, o estudo busca colaborar para a identificação das estratégias que o setor privado vem adotando no Brasil e que podem indicar o crescimento da governança corporativa educacional.

\section{Palavras-chave}

Pacto pela Educação do Pará, Parceiria Público- Privado, Educação Básica.

\section{Introdução}

O presente trabalho tem por objetivo a caracterização do programa denominado Pacto pela Educação do estado do Pará, que possui como principais parceiros, instituições do setor privado. Pesquisas anteriores (Adrião 2009; Adrião et al 2013; Clade, 2013) indicam a presença de instituições privadas cada vez mais especializadas na educação pública,seja por meio da definição de políticas curriculares, via venda dos Sistemas Privados de Ensino, da aquisição pelas redes públicas de "assessoras de gestão", ou por meio do subsídio público à oferta educacional privadas.

Buscando auxiliar no entendimento dos processos de privatização $d$ a educação básica pública, identifica uma nova dinâmica que aqui, como em pesquisa elaborada pela Campanha Latino Americana de Direito à Educação (2013) denominamos "Governança Corporativa Educacional". Segundo a pesquisa, tal processo de privatização significa "(...) a participação direta de representantes de corporações na definição da agenda da educação pública através de mecanismos que não consultam os espaços de participação social para a deliberação e a tomada democrática de decisões sobre a política pública" (CLADE, 2014, p.21). E atua pela presença e participação de redes empresariais que atuam em conjunto por estratégia de "lobbing" na oferta de educação pública, pela presença de programas desenvolvidos por empresas privadas que acabam por definir a agenda da política pública e por fim, pela presença de representantes de empresas e corporações em cargos públicos.

Tendo este pressuposto, este trabalho apresenta levantamento realizado a partir dos programas encontrados nos sites das secretarias de educação do estado do Pará dos anos de 2005 a 2015, que tenham como principais parceiros instituições privadas. Além disso, utilizou-se o Programa NetDraw com objetivo de facilitar a percepção do leitor a respeito das relações existentes entre as instituições privadas e as ações desenvolvidas durante a vigência do pacto.

\section{Resultados e Discussão}

Por constituir parte de uma pesquisa em andamento, os resultados se referem a uma caracterização inicial dos programas que integram o Pacto pela Educação no estado do Pará, e busca identificar as principais empresas e instituições do setor privado em parceria com os programas da rede estadual de educação.

Percebeu-se que 20 instituições atuam diretamente na definição da agenda educativa da rede estadual de ensino do Pará durante o período investigado (2012-2015) como apoiadores, parceiros de governança, parceiros técnicos e coordenação. A atuação envolve a presença das instituições privadas principalmente nas áreas de gestão, capacitação de professores e alunos, ampliação, acesso à tecnologia e controle de evasão e defasagem idade-série.

\section{Agradecimentos}

Agradeço ao CNPq pela oportunidade de desenvolver o projeto e participar deste Congresso e ao GREPPE (Grupo de Estudo e Pesquisa em Políticas Educacionais) pela oportunidade de participar e colaborar com a pesquisa "MAPEAMENTO DAS ESTRATÉGIAS DE PRIVATIZAÇÃO DA EDUCAÇÃO BÁSICA NO BRASIL (2005-2015)" além de outras atividades desenvolvidas que promovem o meu desenvolvimento não só acadêmico, mas o meu desenvolvimento como cidadã.

ADRIÃO, T.. Indicações e Reflexões sobre as Relações entre Esferas Públicas e Privadas para a Oferta Educacional no Brasil. Políticas Educativas, v. 3, p. 1-1, 2009.

ADRIÃO, T.. Privatização da educação no Brasil: estratégias de regulação pelo setor privado da educação obrigatória.. In: Jeffrey, D: Aguilar, Luis.. (Org.). Balanço da Política Educacional Brasileira (1999-2009). 1ed.Campinas: Mercado das Letras, 2013, v. 1, p. 1-19.

CLADE. Mapeo sobre Tendencias de la Privatización de la Educación en América Latina y el Caribe. Campaña Latinoamericana por el Derecho a la Educación. 2014 